\title{
Sabun Üretimi Bakımından Kent Kimliği ve Sabunhanelerin Endüstriyel Miras Kapsamında Değerlendirilmesi: Antakya Örneği
}

\author{
Soap Production in Terms of Urban Identity and Evaluation of Soap Factorles Within the \\ Industrial Heritage: The Case of Antakya
}

Çetin Furkan USUN ${ }^{1}$ (D), Yücel DİNÇ ${ }^{1}$ (D)

${ }^{1}$ Hatay Mustafa Kemal Üniversitesi, Fen Edebiyat Fakültesi, Coğrafya Bölümü, Antakya, Türkiye

ORCID: Ç.F.U. 0000-0002-5205-8752; Y.D. 0000-0002-0492-4724

\section{Öz}

Şehirlerin tarihi dokularını oluşturan alanlarda, asırlık bir gelenek olarak sürdürülen beşeri faaliyetler ve tarihi yapılar kent kimliğinin önemli bileşenleri olmakla birlikte, aynı zamanda birer miras niteliği de taşımaktadır. Bu çalışmanın temel amacı, Antakya'da sabun üretim faaliyetlerinin ve tarihi sabunhanelerin kimlik-endüstriyel miras-turizm bakımından önemine dikkat çekmektir. Bu amaca yönelik olarak öncelikle sabun üretiminin kent kimliği ile olan ilişkileri üzerinde durulmuştur. Diğer yandan, Koruma-Uygulama ve Denetleme Bürosu'ndan (KUDEB) tarihi yapılara yönelik envanterler ve koruma amaçlı imar planı temin edilmiş ve bu veriler yardımıyla sabunhanelerin mekânsal dağılışları ortaya konulmuştur. Bu çalışmadan elde edilen bulgulara dayanarak, Antakya'da sabun üretiminin ve sabunhanelerin kent kimliğinin önem bir bileşeni olduğu, araştırma sahasında tespit edilen sekiz adet sabunhanenin tarihi doku içerisinde ve birbirlerine yakın konumlarda yer aldıkları ve bu sabunhanelerden dördünün yeniden işlevlendirilmesi gerektiği ortaya konulmuştur. Ayrıca, sabunhanelere yönelik geliştirilen endüstriyel miras rotasının tarihi ve kültürel turizm bakımından önemli olduğu vurgulanmış ve yeni kültür rotalarının da geliştirilmesi gerektiği önerilmiştir.

Anahtar kelimeler: Kent Kimliği, Endüstri Mirası, Antakya

\section{ABSTRACT}

Human activities and historical structures, which are located in the areas that constitute the historical textures of the cities and maintained as a centuriesold tradition, are important components of the identity of the city. The main purpose of this study is to draw attention to the importance of soap production activities in Antakya in terms of identity-industrial heritage and tourism. For this purpose, firstly the relationship between soap production and urban identity has been emphasized. . In addition to, inventories and historical development plans have been obtained from the Conservation-Implementation and Inspection Bureau and the spatial distribution of the soap factories has been determined with the help of these data. Based on the findings obtained from this study, it has revealed that soap production and soap factories in Antakya are an important component of urban identity, 8 soap factories identified in the research area are located in the historical texture and close to each other. 4 of these soap factories should be re-functionalized. In addition, it has emphasized that the industrial heritage route developed for soap factories are important in terms of historical and cultural tourism and also it has suggested that new cultural routes should be developed.

Keywords: Urban Identity, Industrial Heritage, Antakya

Başvuru/Submitted: 30.09.2019 • Revizyon Talebi/Revision Requested: 11.12.2019 • Kabul/Accepted: 28.01 .2020 •

Online Yayın/Published Online: 22.04.2020

Sorumlu yazar/Corresponding author: Çetin Furkan USUN / cfusun@mku.edu.tr

Atıf/Citation: Usun, ÇF., Dinc, Y. (2020). Sabun üretimi bakımından kent kimliği ve sabunhanelerin endüstriyel miras kapsamında değerlendirilmesi: Antakya örneği. Cografya Dergisi. Advance online publication.

https://doi.org/10.26650/JGEOG2019-0040 


\section{EXTENDED ABSTRACT}

Identity is defined as the sum of the properties that determine any object. Urban identity is a meaningful integrity that affects the image of the city, whose characteristics are different in each city, shaped by natural, cultural and socio-economic elements, which is formed by the citizens and their lifestyles and which creates the concept of sustainable city. Cities create unique urban identities thanks to their spatial and socio-cultural characteristics. The unique qualities that distinguish a city from other cities constitute the identity of that city. While some of the cities come to the forefront with the tourism sector, some are known for their cultural elements and others for their features such as health function. Antakya, which is the subject of this research has the feature of being a multi-identity city. The culture of soap production, which has been maintained for many years, and the soap factories are among the important elements that make up the urban identity of Antakya. Previously, soap production activities which carried out at home began to be realized in soap factories XIX. century. But soap factories have begun to lose their functions since the middle of the XX. century. The aim of this study is to draw attention to the importance of both soap production activities carried out in Antakya and the structures used as soap factory in certain periods in terms of urban identity. Another aim of the study is to identify the soap factories that are important for industrial heritage and to develop proposals for the re-evaluation of these structures within the scope of conservation-use and integrated with the tourism sector. For this purposes, the main research questions that guide this study are;

- Can soap production and soap factories be considered among the elements constituting Antakya's urban identity?

- What is the spatial distribution of the soap factories and what are the factors affecting this distribution?

- Can the soap factories in Antakya be considered within the scope of industrial heritage and industrial heritage tourism?

- Can a cultural route be established for soap factories in terms of industrial heritage tourism?

In this study, a list of buildings with industrial heritage value in Hatay have been obtained from the Ankara Regional Directorate of Conservation Implementation and Inspection Bureau. On the other hand, the conservation zoning plan and inventories related to the protected structures have been obtained from KUDEB unit of Hatay Metropolitan Municipality. The information obtained from the observations and interviews made in the research area have constituted the other important data of this study.

During the research first of all, the concept of urban identity has been emphasized and the relationship between soap production and urban identity has been revealed. Soap factories with industrial heritage value have been identified and these structures have been processed on the map of conservation zoning plan. Thus, the spatial distribution of the structures that serve as soap factory in certain periods and the reasons of this distribution have been emphasized. The periods in which these structures were built, operated as soap factory, lost their functions and were re-functionalized have been revealed. In addition, the current use of the buildings has been determined. Recommendations have been put forward for the re-evaluation of historical soap factories which have not yet been functionalized within the scope of conservation-use, and then a culture route for soap factories has been proposed. In the research area, 8 structures known to have been used as soap factory in the past have been identified. Soap factories continued their activities until the middle of the XX. century, but later they began to lose their functions due to various reasons. Soap factories operating in Antakya in certain periods; Soap Factory on Bedesten Street, Ömer Şenek Soap Factory, Çelenkçioğlu Soap Factory, Kuseyri Soap Factory, Hasan Ökten Soap Factory, Aselcioğlu Soap Factory, Şeyhoğlu Soap Factory and Selahattin Ökten Soap Factory.

In this study, an industrial heritage route has been developed to draw attention to the identity-culture-tourism interaction in Antakya with the example of soap factories. This route starts from the Hatay Governorship. Afterwards, it reaches to Suphi Bedir Uluç Street via Hürriyet Street, Uzun Çarşı Street and Tayfur Sökmen Street, and from there it connects with Kurtuluş Street and extends to Selahattin Ökten Soap Factory. The route has a length of about 1.5 kilometers. In this study, it has been revealed that the structures which were used as soap factory in certain periods started to operate in the XIX. century and lost their functions after the second half of the XX. century. Soap factories which lost their functions were taken under protection to be registered between 1982-2005. It is revealed that four of all the soap factories in the research area have been functional and the other four have been not functional yet. 


\section{GÍRIŞ}

Türk Dil Kurumu'na göre kimlik; herhangi bir nesneyi belirlemeye yarayan özelliklerin bütünü olarak tanımlanmaktadır (TDK). Genel olarak kimlik kavramı, canlılar ya da nesneler için ayırt edici, farklılık yaratan özellikler olarak tanımlanabilir (Baalawi, 2016, s. 4). Kent kimliği ise, kent imgesini etkileyen, karakteristik özellikleri her kentte birbirinden farklı olan, doğal, kültürel ve sosyoekonomik unsurlarla şekillenen, kentliler ve onların yaşam biçimlerinin oluşturduğu, gelişime açık ve sürdürülebilir kent kavramını yaşatan anlam yüklü bütünlüktür (Koyuncu, 2013). Bir kentin sakinleri tarafından gerçekleştirilen çeşitli faaliyetler, zamanla o kente özgü bazı karakteristik özelliklerin ortaya çıkmasına ve hatta bu özelliklerin coğrafi peyzaj üzerinde etkili olmasına yol açmaktadır (Göney, 2017, s. 6).

Kentler, sahip oldukları mekânsal ve sosyo-kültürel özellikleri sayesinde özgün kent kimliklerinin oluşmasına neden olmaktadırlar. Bir kenti anlatırken onu diğer kentlerden ayıran özgün nitelikleri o kentin kimliğini oluşturur. Kentlere özgü nitelikler doğal unsurlar olabileceği gibi, beşeri faaliyetler veya doğal ve beşeri faaliyetlerin birlikte oluşturduğu unsurlar olabilir. Nitekim Aly (2011), kent kimliğinin fiziki ortam, beşeri aktiviteler ve anlam olmak üzere üç temel elemanının olduğunu ifade etmektedir (Aly, 2011). Doğal ve beşeri faktörlerin uzun yıllar içerisinde birlikte meydana getirdikleri kültürel değerler, insanların belleklerinde bir kent imajının doğmasına neden olmaktadır. Böylece kentler ve kentlere özgü nitelikler, insanların zihinlerinde daha fazla anlam kazanmaya başlar. Anlamlı hale gelen kent kimliği öğeleri, kentte yaşayanların bu öğelere sahip çıkmaya başlamasına ve kente yönelik aidiyet duygularının gelişmesine neden olur.

$\mathrm{Bu}$ araştırmaya konu olan Antakya kenti, çok kimlikli bir kent olma özelliğine sahiptir (Kaypak, 2010, s. 384). Antakya'nın dar ve dolambaçlı sokakları, mozaik müzesi, üç semavi dine ait ibadethaneleri, tarihi yapıları ve gastronomi kültürü gibi unsurları kentin kimliği ile adeta özdeşlemiş durumdadır. Antakya'da, uzun y1llar boyunca süregelen sabun üretim kültürü ve sabunhaneler de kentin kimliğini oluşturan önemli unsurlar arasında yer alır. Önceleri evlerde gerçekleştirilen sabun üretim faaliyetleri, XIX. yüzyıldan itibaren sabunhanelerde devam etmiş, ancak sabunhaneler XX. yüzyılın ortalarından itibaren işlevlerini yitirmeye başlamışlardır. Ülkemizde, Antakya'nın da içerisinde yer aldığı çok sayıda kentte, özellikle 1950'li yıllardan sonra nüfusun hızla artması ve bu sayede meydana gelen hizlı kentleşme süreci, kentlere özgü bazı karakterlerin, kültürlerin ve kimliklerin değişimine ve yitirilmesine yol açmıştır. Şüphesiz bu durum, tarihi ve kültürel öneme sahip olan soyut ve somut kültür öğelerinin korunmasını gündeme getirmiştir.

Antakya, kendi kimliğini koruyabilen çok az sayıdaki kentten biridir. Antakya'nın tarihi dokusu içerisinde yaşam bugün de devam eder (Kaypak, 2010, s. 384). Bu tarihi doku, Eski Antakya olarak bilinen ve Asi Nehri'nin doğu yakası ile Habib-i Neccar Dağı etekleri arasındaki sahada yer almaktadır (Dinç, 2015, s. 111). Antakya'da, günümüze kadar ayakta kalabilen ve bir asırdan fazla tarihi geçmişe sahip olan yapılar, Eski Antakya'da kentsel ve arkeolojik sit alanları içerisindedir (Sargın ve Dinç, 2017, s. 482). Sınırları bu şekilde belirlenmiş olan bu alan, aynı zamanda bu makalenin araştırma sahasını oluşturmaktadır (Şekil 1). Antakya kentinde, tescillenerek koruma altına alınmış olan yapıların tamamına yakını araştırma sahası sınırları içerisinde yer almaktadır.

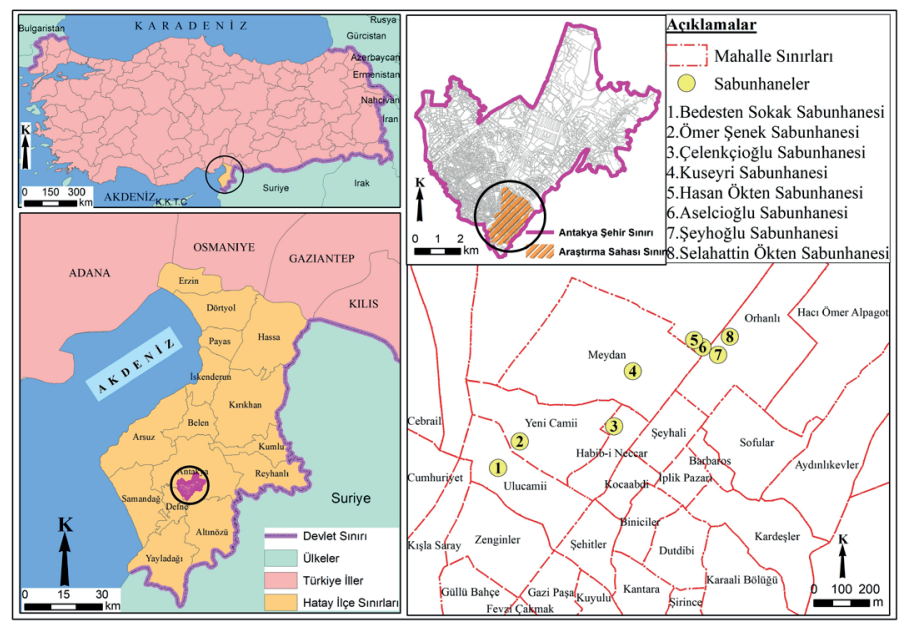

Şekil 1: Araştırma Sahasının Lokasyon Haritası.

Figure 1: Location Map of Research Area.

\section{AMAÇ VE YÖNTEM}

Çalışmanın başlıca araştırma soruları; (1) Sabun üretimi ve sabunhaneler Antakya'nın kent kimliğini oluşturan unsurlar arasında sayılabilir mi? (2) Sabunhanelerin mekânsal dă̆gllş̧ları nasildır ve bu dağıllş̧ı etkileyen faktörler nelerdir? (3) Antakya'daki sabunhaneler endüstriyel miras ve endüstriyel miras turizmi kapsamında değerlendirilebilir mi? (4) Endüstriyel miras turizmine yönelik olarak sabunhaneler üzerinden bir kültür rotası (güzergah) belirlenebilir mi? $\mathrm{Bu}$ araştırma sorularından hareketle makalenin amac1; Antakya'da gerçekleştirilen sabun üretim faaliyetlerinin ve belirli dönemlerde sabunhane olarak kullanılan yapıların kent kimliği bakımından önemine dikkat çekmek ve kentte, endüstriyel miras değeri taşıyan sabunhaneleri tespit ederek bu yapıların korumakullanma kapsamında ve turizm sektörüyle entegre bir şekilde yeniden değerlendirilmesine yönelik öneriler geliştirmektir. 
$\mathrm{Bu}$ makalede, araştırma sahası ve konusu ile ilgili önceden yapılmış olan çalışmalardan yararlanılmış, çalışmanın amaçları doğrultusunda, Koruma Uygulama ve Denetleme Bürosu (KUDEB) Ankara Bölge Müdürlüğü’nden Hatay'da endüstriyel miras değeri taşıyan yapıların listesi temin edilmiştir. Diğer yandan Hatay Büyükşehir Belediyesi bünyesinde faaliyet gösteren KUDEB biriminden koruma amaçlı imar planı ve koruma altına alınmış yapılarla ilgili envanterler elde edilmiş̧ir. Araştırma sahasında yapılan gözlemlerden ve mülakatlardan elde edilen bilgiler, çalışmanın diğer önemli verilerini oluşturmuştur.

Çalı̧̧mada, öncelikle kent kimliği kavramı üzerinde durulmuş, sabun üretiminin kent kimliği ile olan ilişkileri; kurumsal kimlikler, Antakya'da çekilen diziler, Defne isminin geçtiği işletme ve yer adları ve coğrafi işaretler yardımıyla ortaya konulmuştur. Endüstriyel miras değeri taşıyan sabunhaneler, KUDEB'ten elde edilen verilerden ve arazi çalışmaları sırasında yapılan gözlemlerden hareketle tespit edilmiş ve bu yapılar, koruma amaçlı imar planı haritası üzerine işlenmiştir. Böylece belirli dönemlerde sabunhane olarak hizmet veren yapıların mekânsal dağılışları ve bu dağılışın sebepleri üzerinde durulmuştur. Söz konusu yapıların inşa edildikleri, sabunhane olarak faaliyet gösterdikleri, işlevlerini kaybettikleri ve yeniden işlevlendirildiği dönemler ve yapıların mevcut kullanım durumları ortaya konulmuştur. Henüz işlevlendirilmemiş durumda olan tarihi sabunhanelerin koruma-kullanma kapsamında yeniden değerlendirilmelerine yönelik öneriler ileri sürülmüş ve sabunhanelerin endüstriyel miras turizmi bakımından taşıdıkları öneme dikkat çekebilmek için sabunhanelere yönelik bir kültür rotası önerisi getirilmiştir.

\section{BULGULAR VE TARTIŞMA}

\subsection{Antakya'da Sabun Üretimi Bakımından Kent Kimliği}

Antakya'nın sabun üretimi bakımından kent kimliği incelendiğinde, her şeyden önce sabunun ham maddesini oluşturan defne ve zeytinin, Antakya ve çevresinin doğal ortam şartları içerisinde geniş yayılış alanlarına sahip olduğu dikkati çekmektedir. Nitekim bu sahada, ortalama sıcaklıkların $18^{\circ} \mathrm{C}$ 'den fazla olması, kış sıcaklıklarının $0^{\circ} \mathrm{C}$ 'nin altına düşmemesi, vejetasyon süresinin yılın tamamına yayılması ve yaz aylarının sıcak ve kurak geçmesi maki bitkilerinin oldukça iyi bir dinamizm göstermelerine neden olmaktadır (Kaya ve Aladağ, 2009, s. 71). Bu nedenle, Antakya ve çevresinde defne ve zeytin için elverişli iklim şartlarının varlığı, sabun üretiminin fazla olmasını beraberinde getirmiştir. Böylece, her iki bitkiden elde edilen yağlar, bu yağlardan elde edilen sabunlar ve sabun üretiminin gerçekleştirildiği sabunhaneler, gerek yerel halkın gerekse kente gelen ziyaretçilerin belleklerinde anlam kazanmaktadır. Bu durum, Antakya'nın kent imajında sabunun da önemli bir yere sahip olduğunu gösterir.

Antakya'da, sabun üretim faaliyetleri özellikle son birkaç yüzyıl içerisinde dikkate değer bir gelişme göstermiş̧tir (Temiz, 2008). Osmanlı döneminde sabun üretimi, "sabunhane" olarak adlandırlan tesislerde gerçekleştirilmiştir (Camuz, İpeklioğlu ve Böke, 2015, s. 14). Antakya'daki sabunhanelerle ilgili yapılan bilimsel çalışmalar, Antakya halkının sabunhanelerle XIX. yüzyılda tanışmaya başladığını ortaya koymaktadır (Çelenk, 1996; Temiz, 2008; Camuz vd, 2015). Bu yapılardan bazıları XIX. yüzyılda doğrudan sabunhane olarak inşa edilmiştir. Daha önceki yüzyıllarda inşa edilmiş olan bedesten, kervansaray ve han gibi bazı yapıların ise XIX. yüzyıla gelindiğinde sabunhane olarak hizmet vermeye başladıkları bilinmektedir. Antakya'da sabunhanelerin oldukça yoğun bir şekilde faaliyet gösterdiği XIX. yüzyılda, sabunculuk mesleğinin şehirde ön plana çıkmış meslekler arasında yer aldığı ve üretimin de fazla olduğu dikkati çekmektedir (Ayçiçek, 2017, s. 97). Nitekim 1822 yılında yayımlanmış olan Lugat-1 Tarihiyye ve Coğrafiyye'de, Antakya'da 1.560 .500 okka $^{1}$ (yaklaşık 2 milyon ton) zeytin üretilmiş olduğu kayıtlara geçmiştir (Ahmet Rıfat Efendi, 1881). Diğer yandan Ali Cevad'ın 1895 yılında yayımlamış olduğu Memalik-i Osmaniye'nin Tarih ve Coğrafya Lugatı isimli eserinde ise Antakya'da her yll ortalama 1.300 .000 okka (1 milyon 650 bin tondan fazla) sabun üretilmekte olduğu belirtilmiştir (Ali Cevat Bey, 1895).

Antakya'da yer alan sabunhanelerin XX. yüzyılın ilk yarısındaki durumunu ortaya koyan çalışmalardan birini Weulersse yapmıştır. Antakya'y1 1930'lu yıllarda gezen ve kentle ilgili gözlemlerini dile getiren Weulersse, o dönemde Antakya'da on altı sabunhanenin yer aldığını ve bunlardan on tanesinin çalışır durumda olduğunu belirtmiştir. Weulersse, Antakya ve çevresinde geniş zeytinlik arazilerin var olmasının sabun üretimi ve ticaretini teşvik ettiğini ve sabunhanelerde üretilen sabunların Ankara, Amasya, Diyarbakır, Mardin, Musul ve Van'a gönderildiğini ifade etmiştir (Weulersse, 1934, s. 66). Antakya'da, XX. yüzyılın ikinci yarısından sonra sabunhanelerin işlevlerini yitirmeye başladıkları ve sayılarının azaldığı dikkati çekmiştir. Nitekim araştırma sahasında, geçmiş dönemlerde sabunhane olarak faaliyet gösterdiği bilinen sadece sekiz adet yapı tespit edilmiştir. Sabunhaneler, XX. yüzyılın ortalarına kadar faaliyetlerini sürdürmüşler, ancak daha sonraki süreçte kırsal alanlardan kente

1 Okka, Osmanlı döneminde kullanılan bir ağırlık ölçü birimi olup, 1 okka 1,2828 kilograma karşılık gelmektedir (Hınz, 1990: 30). 
yönelik gerçekleşen göçler, kent nüfusunun hızla artması ve kentin genişlemesi neticesinde işlevlerini yitirmeye başlamışlardır. Tarihi öneme sahip sabunhanelerin çoğu, sabun üretimini durdurmuş olsalar da, günümüzde Antakya ve çevresinde sabun üretimi gerek evlerde gerekse kentin kenar kesimlerindeki atölyelerde üretilmeye devam etmektedir (Fotoğraf 1). Bu atölyelerde uluslararası standartlara uygun şekilde sabun üretilmekte ve üretilen sabunlar Avrupa ve Ortadoğu ülkelerine ihraç edilmektedir. ${ }^{2}$

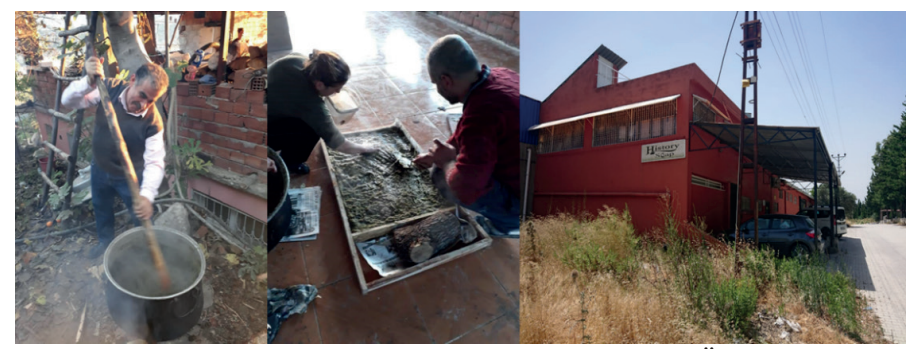

Fotoğraf 1: Ev ve Atölyelerde Defne Sabunu Üretimi.

Photo 1: Laurel Soap Production Process in Houses and Workshops.

Antakya'nın gastronomi alanında UNESCO yaratıcı kentler ağına girmesi, EXPO 2021'in Hatay'da düzenlenecek olmas1, Antakya'da çekilen dizi ve filmlerin artması, sosyal medyanın etkin kullanımı, ulusal ve uluslararası konferans ve festivallerde kentin daha iyi tanıtılması, kente yönelik düzenlenen turların yaygınlaştırılması gibi faktörler, kenti ve kent kimliğini yansıtan bileşenleri ön plana çıkarmıştır. Bunlar içerisinde, sabun ve sabunhaneler de yer almaktadır. Nitekim sabunhanelerin endüstriyel miras kapsamında tescillenmesi, kentteki belli başlı kurumların logolarında defne ve zeytin yaprağının yer alması (Şekil 2), kentte çekilen dizi ve filmlerde sabun üretimine yer verilmesi, defne sabununun coğrafi işaret olarak tescil edilmesi, turizm tesislerinde sabun satış reyonlarının var olması gibi faktörler, sabun üretiminin kent kimliği bakımından önemini ortaya koymaktadır.

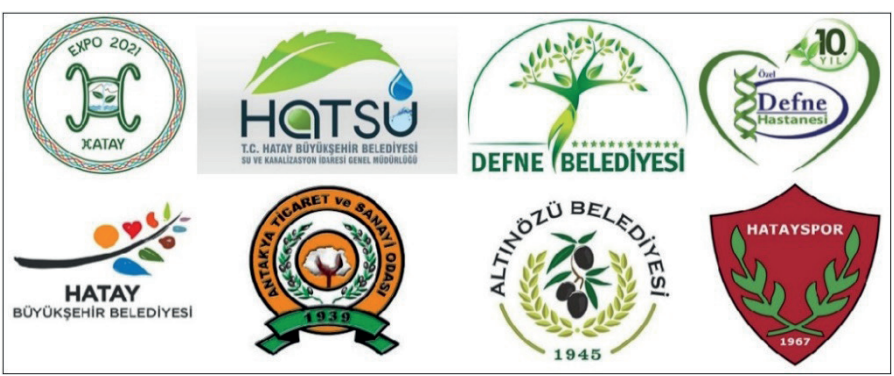

Şekil 2: Antakya'da Defne ve Zeytin Yaprağının Kullanıldığı Kurumsal Kimlik Logoları.

Figure 2: Institution Identity Logos Where Laurel and Olive Leaves are Used in Antakya.
Günümüzde çoğunluğu işlevini yitirmiş durumda olan sabunhanelerden sadece Selahattin Ökten Sabunhanesi (Verdaa), geleneksel yöntemlerle sabun üretimine devam etmektedir. Selahattin Ökten Sabunhanesi dışındaki sabunhaneler eski işlevlerini büyük oranda yitirmiş olsalar da, kentin sabun üretimi ve sabun kültürü bakımından sahip olduğu kimlik bugün de varlığını sürdürmektedir. Sabun üretim kültürünün "Antioch's Verdaa" adı altında markalaşması ve bu sayede defne sabununun daha fazla tanıtılması kent kimliğini güçlendirmektedir. Diğer yandan 2003 yılında bir otel olarak yeniden işlevlendirilen tarihi Şeyhoğlu Sabunhanesi (Savon Otel), endüstriyel miras turizminin somut bir örneği olarak kent kimliğini yansıtmaktadır. Otelin adını taşıyan "Savon" kelimesinin sabun anlamına gelmesi, kenti ziyaret eden turistlerin belleklerinde bir sabun kültürünün (imajının) yer edinebilmesi bakımından dikkat çekicidir. Nitekim daha önce Antakya'yı ziyaret etmiş ve Savon Otel'de konaklamış olan gazeteci yazar Hıncal Uluç, bu tarihi yapı ile ilgili izlenimlerini bir köşe yazısında paylaşmıştır. Bu gözlemler, sabun üretiminin turistler tarafindan nasıl algılandığını ve ne anlam ifade ettiğini göstermesi bakımından önem arz etmektedir.

"Yasemin, Hatay gezimizi planlayan Hüseyin Yayman dostumuzla konuşup programı getirdi. Savon Otel'de kalıyormuşuz. Lafi doğru anla dedim Yaso 'ya...Savon, sabun demek, sabun diye bir otel mi olur?... Bu herhalde Savoy olmalı. Karayolu ile gelecek Öcal abim ile Ercan'a olmayan bir oteli aratma. Meğer kiza haksızlık etmişim. Otel'in adv gerçekten Savon iyi mi?... sabun yani...Çünkü Fransızlar zamanında sabun fabrikasıymış burası ...2006'da tıpkisınin aynisı restore edilmiş ve bir butik otele dönüşürü̈lmüss. Savon Fabrikası, olmuş Savon Otel...5 yıldızlı... Butik..."3

\subsection{Endüstriyel Miras Kavramı ve Hatay'ın Endüstriyel Miras Değerleri}

Uluslararas1 Endüstri Mirasını Koruma Komitesinin tanımına ${ }^{4}$ göre endüstri mirası; "endüstri kültürünün tarihi, teknolojik, sosyal, mimari ve bilimsel değeri olan kalıntılarından oluşur. Bu kalıntılar; endüstri ile iliş̧kili yapılar ve makineler, imalathaneler, fabrikalar, maden ocaklar, rafineriler gibi üretim alanlarl, depolar ve dükkânlar, enerjinin üretildiği, dă̆gtıldiğl ve kullanıldiğg alanlar, ulaşım ve buna ilişkin tüm altyapılar ve bunların yanı sıra konut, eğitim vb. endüstri ile ilişkili tüm sosyal aktivite alanlarından oluşur." İşlevini kaybetmiş her türlü

2 History Soap sabun atölyesinin pazarlama sorumlusu Tamer Uludağ ile gerçekleştirilen mülakat (Mülakat Tarihi: 17.07.2019).

3 https://www.sabah.com.tr/yazarlar/uluc/2018/10/26/sabun-diye-bir-otel

4 http://ticcih.org/about/charter/, Erişim Tarihi: 03.09.2019 
endüstri yapısı, bir döneme tanıklık etmiş, yaşanmışlıkları olan, kentte ve kentlide iz birakan somut deliller olması nedeniyle korunması gereken kültür varlıklarıdır (Aydın ve Aksoy, 2012). Tarihi öneme sahip olan ve birer miras değeri gösteren endüstriyel yapıların korunmasına yönelik ilk girişimler, 1978 yılında Uluslararası Endüstri Mirası Komitesinin kurulması sonrasında gerçekleşmiştir (Barbaros Akay ve Örmercioğlu, 2018). UNESCO'nun 2001 yılından itibaren endüstri mirasını ayrı bir başlık (Karadağ ve İncedere, 2017, s. 17) olarak ele almasıyla da endüstri mirası kavramı uluslararası platformda kabul gören bir olgu haline gelmiştir (Barbaros Akay ve Örmercioğlu, 2018). Bunlar dişında, günümüzde ICOMOS, ERIH, E-FAITH ve DOCOMOMO gibi örgütler ve platformlar da endüstri miras1 konusunda önemli uluslararası çalışmalar yürütmektedir.

Dünyadaki bu gelişmelerin yanında, endüstri devrimini geç deneyimlemiş ülkemizin endüstri mirası kavramıyla tanışmasının da temelleri oldukça yenidir (Saner, 2012). Türkiye'de endüstri mirası kavramı Osmanlı döneminde ve Cumhuriyetin ilk yıllarında yapılan ve sonrasında işlevlerini yitirerek koruma altına alınan endüstri yapıları için 1990'larda gündemimize girmiştir. Dolayısıyla endüstri mirası değeri bulunan yapıların kullanım zamanları çok eskiye gitse de, bu yapıların oluşturmuş olduğu endüstri mirası kavramı oldukça yenidir. Türkiye'de bulunan 4.171 tescilli endüstriyel ve ticari yapının 45'i ülkemiz sınırlarının en güneyini oluşturan Hatay ilinde bulunmaktadır. Hatay, bu 45 adet tescilli yapı ile Türkiye'nin endüstri mirası değerleri bakımından dikkat çeken öneme sahip iller arasındadır.

Hatay'da yer alan 45 adet tescilli yapının türlere göre dağılımı incelendiğinde, bu yapıların on yedisinin konut ve işyeri, on ikisinin ticarethane, sekizinin sabunhane, üçünün işlik, ikisinin atölyeden oluştuğu, bunlar dişında birer adet ambar, elektrik üretim santrali ve mezbahanenin yer aldığı görülmektedir (KUDEB, 2019). Diğer yandan tescilli endüstriyel ve ticari yapıların ilçelere göre dağılımı incelendiğinde ise bu yapıların 36'sının Antakya'da yer aldığı görülür. Bununla birlikte Hatay ilindeki toplam sekiz adet sabunhanenin tamamı Antakya'da bulunmaktadır. Geriye kalan dokuz yapının dördü İskenderun'da, ikisi Yayladağı'nda yer alırken, Defne, Reyhanlı ve Samandağ ilçelerinde de birer adet yapı bulunmaktadır.

\subsection{Antakya'da Yer Alan Sabunhanelerin Endüstriyel Miras Kapsamında Değerlendirilmesi}

Kentlere özgü kültürel değerlerin uzun ylllar içerisinde meydana getirdiği kent kimlikleri, genellikle o kentlerin tarihi dokularını oluşturan alanlarda yer almaktadır (Polat, Polat Aktaş ve Halis, 2013). Bunun temel sebeplerinden biri, bir kente özgü kültürel değerlerin ve alışkanlıkların tarihi süreç içerisinde ve nispeten uzun bir zaman diliminde oluşmasıdır. Tarih boyunca birçok medeniyete ev sahipliği yapmış olan Antakya, kuruluşundan XIX. yüzyılın sonlarına kadarki süreçte Asi Nehri'nin doğu yakasında, Habib-i Neccar Dağı eteklerinde varlığını sürdürmüştür. Şehir, son büyük depremin yaşandığı 1872 yılına kadar surlar içerisinde adeta sıkışıp kalmıştır (Dinç, 2015, s. 111). XIX. yüzyılın ortalarında Antakya'nın surlar dışında bir mahalleye sahip olmadı̆̆ bilinmektedir (Türk, 2012, s. 221). Bu bilgilerden hareketle, Antakya'da günümüze kadar ayakta kalabilen ve bir asırdan fazla tarihi geçmişe sahip olan yapıların, neden Eski Antakya'da yoğunluk kazanmış oldukları daha iyi anlaşılmaktadır.

Tarihi ve kültürel değerleri yansıtan ve geçmişin izlerini somut bir şekilde ortaya koyan Eski Antakya'da, geleneksel konutlardan çeşmelere, hamamlardan bedestenlere, tarihi camilerden havra ve kiliselere kadar çok sayıda tarihi yapı yer almaktadır (Sargın ve Dinç, 2017, s. 482). Şehirde bu yapıların yanı sıra, XIX. yüzyılda faaliyet göstermeye başlamış ve günümüzde işlevlerini büyük ölçüde yitirmiş olan sabunhaneler de yer alır. Araştırma sahasında, geçmiş dönemlerde birer sabunhane olarak faaliyet göstermiş olan toplam sekiz adet yap1 tespit edilmiştir. Sabunhanelerin XX. yüzyllın ortalarından itibaren üretimlerini durdurmaları ve işlevsiz hale gelmeleri, tarihi öneme sahip bu yapıların endüstriyel miras kapsamında korunmasını gerekli hale getirmiştir.

Antakya'da, koruma altına alınan yapıların tescillenmesi işlemleri farklı dönemlerde farklı kurumlar aracılığıyla gerçekleşmiştir. Yapıların tescillenmesi görevini 1975 yılında Gayrimenkul Eski Eserler ve Anttlar Yüksek Kurulu, 1985 yılında Kültür ve Tabiat Varlıklarını Koruma Kurulu ve 2010 y1lından itibaren de Koruma Uygulama ve Denetim Bürosu (KUDEB) üstlenmiştir (Sargın ve Dinç, 2017, s. 490). Araştırma sahasında yer alan sabunhanelerin bazıları Gayrimenkul Eski Eserler ve Anitlar Yüksek Kurulu'nun 12.07.1975 tarih ve 8521 sayılı kararına, bazıları ise Kültür ve Tabiat Varlıklarını Koruma Kurulu'nun 15.11.1985 tarih ve 1558 sayılı kararına bağlı kalınarak tescil edilmiştir (Mersinligil ve Erişen, 1997, s. 45).

Antakya'da belirli dönemlerde faaliyet göstermiş olan sabunhaneler; Bedesten Sokak'ta yer alan Sabunhane, Ömer Şenek Sabunhanesi, Çelenkçioğlu Sabunhanesi, Kuseyri Sabunhanesi, Hasan Ökten Sabunhanesi, Aselcioğlu Sabunhanesi, Şeyhoğlu Sabunhanesi ve Selahattin Ökten Sabunhanesidir. Weulersse'nin (1934) Antakya ile ilgili çizmiş olduğu bir harita üzerinden şehrin 1934 yılına ait mekânsal sınırları çizildiğinde, bütün sabunhanelerin şehir sınırları içerisinde yer aldıkları 
görülür. Bedesten Sokak'ta yer alan Sabunhane ile Ömer Şenek, Çelenkçioğlu ve Kuseyri Sabunhanelerinin Antakya'nın tarihi ticaret merkezinde; diğer yandan Hasan Ökten, Aselcioğlu, Şeyhoğlu ve Selahattin Ökten Sabunhanelerinin ise şehrin kuzey kenarında yer aldıkları dikkati çekmektedir.

\subsubsection{Bedesten Sokak Sabunhanesi}

Eski Antakya'da, Kırk Asırlık Türk Yurdu Caddesi, Bedesten Sokak ve Bekir Sitkı Kunt Caddesi arasında yer alan yapının Osmanlı döneminde bir bedesten olarak inşa edildiği bilinmektedir. Arazi çalışmaları sırasında yapılan mülakatlarda, bu bedestenin bir dönem sabunhane olarak faaliyet gösterdiği belirtilmiştir.
Sabunhane, daha sonra işlevini yitirmiş ve yapı, marangozhane olarak faaliyet göstermeye başlamıştır. ${ }^{5}$ Marangozhane olarak kullanıldıktan sonraki süreçte işlevini yitiren yapı, Gayrimenkul Eski Eserler ve Anıtlar Yüksek Kurulunun 11.06.1982 tarih ve 3734 nolu kararıyla ve Kültür ve Tabiat Varlıklarını Koruma Kurulunun 15.11.1985 tarih ve 1558 nolu kararıyla tescillenmiş ve koruma altına alınmıştır. Antakya'da yer alan tescilli yapılar içerisinde 2 numaralı envantere sahip bu yap1, 30 numaralı parselde yer almaktadır (Tablo 1). Yap1, günümüzde işlevlendirilmiş durumda olup, restoran ve künefe salonu olarak faaliyet göstermektedir (Fotoğraf 2a). Yapı bünyesinde, Antakya'daki sabunhanelerde gözlenen tonozlu mimari dışında, sabun üretimine yönelik herhangi bir unsur tespit edilmemiştir.

Tablo 1: Antakya'daki Endüstriyel Miras Kapsamında Değerlendirilen Sabunhaneler Table 1: Soap factories within the scope of industrial heritiage in Antakya

\begin{tabular}{|c|c|c|c|c|c|}
\hline Sabunhane Adı & Konum & Fotoğraf & Envanter & Tescil yılı & Güncel kullanım durumu \\
\hline Bedesten Sokak & $\begin{array}{l}\text { Ulucami Mah. } \\
\text { Bedesten Sk. }\end{array}$ & & 2 & $1982 / 1985$ & $\begin{array}{c}\text { İşlevlendirilmiş } \\
\text { (Restoran/Kafe) }\end{array}$ \\
\hline Ömer Şenek & $\begin{array}{l}\text { Ulucami Mah. } \\
\text { Kemalpaşa Cd. }\end{array}$ & & 55 & $1982 / 1985$ & $\begin{array}{l}\text { İşlevlendirilmemiş } \\
\text { (Restorasyon aş.) }\end{array}$ \\
\hline Çelenkçioğlu & $\begin{array}{l}\text { Meydan Mah. } \\
\text { Tayfur Sökmen Sk. }\end{array}$ & & 108 & 1985 & $\begin{array}{l}\text { İşlevlendirilmiş } \\
\text { (Ticarethaneler) }\end{array}$ \\
\hline Kuseyri & $\begin{array}{l}\text { Meydan Mah. } \\
\text { İne İplik Cd. }\end{array}$ & & 541 & 2009 & $\begin{array}{l}\text { İşlevlendirilmemiş } \\
\text { (Restorasyon aş.) }\end{array}$ \\
\hline Hasan Ökten & $\begin{array}{l}\text { Haraparası Mah. } \\
\text { S.Bedir Uluç Sk. }\end{array}$ & & 336 & 1985 & $\begin{array}{c}\text { İşlevlendirilmemiş } \\
\text { (Restore edilip işlevlendirilmelidir) }\end{array}$ \\
\hline Aselcioğlu & $\begin{array}{l}\text { Haraparası Mah. } \\
\text { S.Bedir Uluç Sk. }\end{array}$ & & 336 & 1985 & $\begin{array}{c}\text { İşlevlendirilmemiş } \\
\text { (Restore edilip işlevlendirilmelidir) }\end{array}$ \\
\hline Şeyhoğlu & $\begin{array}{l}\text { Meydan Mah. } \\
\text { Kurtuluş Cd. }\end{array}$ & & 305 & 1985 & $\begin{array}{l}\text { İşlevlendirilmiş } \\
\text { (Savon Otel) }\end{array}$ \\
\hline Selehattin Ökten & $\begin{array}{l}\text { Orhanlı Mah. } \\
\text { Kurtuluş Cd. }\end{array}$ & & 385 & 2005 & $\begin{array}{c}\text { İşlevlendirilmiş } \\
\text { (Sabun üretimi ve satışı devam ediyor) }\end{array}$ \\
\hline
\end{tabular}

Kaynak: Koruma Uygulama ve Denetleme Bürosu (KUDEB)

5 Tarihi yapının bünyesinde faaliyet gösteren künefe dükkânının işletmecisi Raci Hüyük ile gerçekleştirilen mülakat (Mülakat Tarihi: 06.07.2019) 


\subsection{2. Ömer Şenek Sabunhanesi}

Kemalpaşa Caddesi, Uzun Çarşı Caddesi ve Abacılar Sokak'in kesiştiği noktada yer alan bu tarihi sabunhanenin XIX. yüzyılda Ömer Şenek tarafından yaptırıldı ̆̆ tahmin edilmektedir. İç avlusu olan, iki katlı ve taş yapılı olan sabunhane, Antakya' daki diğer sabunhaneler gibi XX. yüzyılın ikinci yarısında işlevini yitirmiştir. Yapı, Gayrimenkul Eski Eserler ve Anıtlar Yüksek Kurulunun 11.06.1982 tarih ve 3734 nolu kararıyla ve Kültür ve Tabiat Varlıklarını Koruma Kurulunun 15.11.1985 tarih ve 1558 nolu kararıyla tescillenmiş ve koruma altına alınmıştır. Önemli bir endüstriyel miras değeri taşıyan sabunhanenin envanter numarası 55 olup, yap 5 . mintıkada 160 ve 178 numaralı parsellerde yer almaktadır (Tablo 1). Günümüzde restore edilmiş olmasına rağmen henüz işlevlendirilmemiş durumda bulunan Ömer Şenek Sabunhanesinin bir sabun müzesi olarak işlevlendirilmesi düşünülmüş ancak bu proje, henüz hayata geçirilmemiştir (Fotoğraf 2b).

\subsection{3. Çelenkçioğlu Sabunhanesi}

Uzun Çarşı Caddesi, Tayfur Sökmen Caddesi ve Saka Sokak arasında yer alan bu yapının, Osmanlı döneminde bir han olarak inşa edilmiş olduğu bilinmektedir. Bu han, Saka Hamamı ve Mahremiye Cami ile yan yana inşa edilerek bir külliye işlevi gören üçlü yapı grubu elde edilmiştir. Han, 1574 yılında Sokullu Mehmet Paşa tarafindan vakıf olarak yaptııılmıştır. XIX. yüzyıl ortalarına kadar han olarak kullanılan bu yapı, 1842-1845 yılları arasında Halep Valiliği yapan Vecihi Paşa tarafindan sabunhaneye çevrilmiştir. Yapı, 1969 yılına kadar sabunhane olarak faaliyetini sürdürmüştür (Çelenk, 1996, s. 37). 1969 yılında ticari faaliyetlerini durduran Selim Çelenk ve Tahir Necip Haytoğlu Kollektif Şirketi, 1973 yllında şirketin feshedildiğini ilan etmişler ve böylece sabunhanenin ticari faaliyetleri resmen sona ermiştir (Çelenk, 1996, s. 50). Yapı, Kültür ve Tabiat Varlıklarını Koruma Kurulu tarafından 1985 yılında tescillenerek koruma altına alınmıştır. 5-1 mıntıkada, 1262 numaralı parselde yer alan yapının envanter numarası 108'dir (Tablo 1). Günümüzde Defne Han adıyla bilinen yapı ışlevlendirilmiş olup, yapı bünyesinde giyim, züccaciye ve kozmetik ürünleri satan dükkânlar faaliyet göstermektedir (Fotoğraf 2c).

\subsubsection{Kuseyri Sabunhanesi}

Kuseyri Sabunhanesi, Eski Antakya'da tarihi ticaret merkezinin sınırları içerisinde, Meydan Mahallesinde İnne-İplik Caddesinde yer almaktadır. Yapı, XVI. yüzyılda inşa edildiği bilinen Kurşunlu Han ve Sokullu Mehmet Paşa Hanı (Defne Hanı) arasında ve tarihi Kurtuluş Caddesinin batısında yer almaktadır (Camuz vd, 2015, s.
17). Sabunhanenin ne zaman inşa edilmiş olduğu kesin olarak bilinmemekle birlikte, yapının 1892 yılında yayınlanan Annuaire Oriental dergisinde adı geçen sabunhaneler arasında yer alması, sabunhanenin XIX. yüzyılın ikinci yarısında inşa edilmiş olabileceğini göstermektedir (Camuz vd, 2015, s. 17; Camuz, 2016, s. 189). Аnnuaire Oriental dergisinde geçen bilgilere göre sabunhanenin ilk sahibinin Kuseyrizade Hacı Rıfat olduğu bilinmektedir. Günümüzde sabunhane iki bölümden oluşmaktadır. Batı bölümü Rana Salih adına kayıtlı iken, doğu bölümü ise Rana Salih'in amcası olan İhsan Ferit Kuseyri'nin tapusuna kayıtlıdır (Camuz, 2016, s. 189-192). Kuseyri Sabunhanesi, Antakya'daki diğer sabunhaneler gibi (Selahattin Ökten Sabunhanesi hariç), XX. yüzyılın ikinci yarısından sonra üretimini durdurmuş ve işlevini yitirmiştir. Yapı, 2009 yılında Adana Koruma Bölge Kurulu tarafindan tescillenerek koruma altına alınmıştır. 541 envanter numarasına sahip olan yapı, 746 ve 748 nolu parsellerde yer almaktadır (Tablo 1). Tarihi Kuseyri Sabunhanesi, günümüzde restorasyon halinde olup, endüstriyel miras kapsamında yeniden işlevlendirilmeyi beklemektedir (Fotoğraf 2d).

\subsubsection{Hasan Ökten Sabunhanesi}

Suphi Bedir Uluç Sokağında, Aselcioğlu Sabunhanesinin bitişiğinde yer alan Hasan Ökten Sabunhanesinin XIX. yüzyılda inşa edilmiş olduğu tahmin edilmektedir. Sabunhane, bir asırdan fazla faaliyet gösterdikten sonra, XX. yüzyılın sonlarında üretimini durdurmuştur. Yapı, Kültür ve Tabiat Varlıklarını Koruma Kurulu'nun 15.11.1985 tarih ve 1558 nolu karariyla tescillenerek koruma altına alınmıştır. Kentsel sit alanı ve III. derece arkeolojik sit alanı içerisinde, 5. Mıntıkada ve 3777-3778 nolu parsellerde yer alan bu sabunhane, Aselcioğlu Sabunhanesi ile aynı envanter numarasına (No: 336) sahiptir (Tablo 1). Sabunhane günümüzde işlevlendirilmemiş durumdadır (Fotoğraf 2e).

\subsubsection{Aselcioğlu Sabunhanesi}

Aselcioğlu Sabunhanesi, Kurtuluş Caddesi ile Suphi Bedir Uluç Sokak arasında yer almaktadır. Bu sabunhane, batıda Hasan Ökten Sabunhanesi ile doğuda ise Şeyhoğlu Sabunhanesi (Savon Otel) ile komşudur. Söz konusu sabunhanelerin konumları, Antakya'nın 1934 yılına ait şehir sınırları ile ilişkilendirildiğinde, sabunhanelerin şehrin kuzey ucunda (kenarında) yer aldıkları görülmektedir. Antakya'daki 8 adet tarihi sabunhaneden 5 tanesinin bu alanda yer alması, sahanın aslında bir sabunhaneler bölgesi olduğunu göstermektedir. XIX. yüzyılda inşa edilmiş olduğu tahmin edilen Aselci Sabunhanesi günümüzde işlevini yitirmiş olup, harabe (metruk) halindedir. Aselcioğlu Sabunhanesi, Kültür ve Tabiat Varlıklarını Koruma Kurulu'nun 
15.11.1985 tarih ve 1558 nolu karariyla tescillenerek koruma altına alınmıştır. Kentsel sit alanı ve III. derece arkeolojik sit alanı içerisinde, 5. mıntıkada yer alan sabunhane 336 numaralı envantere sahiptir. Yapının bugünkü hali kötü ve kullanım dışıdır (Fotoğraf 2f). Özgün hali ise, bir avlu içerisinde üç yönde çapraz tonoz zemin kat ve kiremit çatılı üst kattan oluşan bir yapıdır (KUDEB, 2019). Yapının, Suphi Bedir Uluç Sokağa bakan kesiminde terzi, spotçu, elektronikçi, fotoğrafçı ve kuaför dükkânları faaliyet göstermektedir.

\subsection{7. Şeyhoğlu Sabunhanesi}

Kurtuluş Caddesi ile Çetin Emeç Caddesi arasında yer alan bu yapı, 1860'lı yıllarda sabunhane olarak inşa edilmiştir. Bu sabunhanede, uzun yıllar zeytinyağı ve sabun üretimi gerçekleştirilmiştir. Doğrudan avluya açılan ve "U" şeklinde tasarlanan yapıda, taş tonozlar ve kemerler kullanılmıştır. Sabunhanede, sabun ve zeytinyağ 1 üretimi 1960 'l 1 y1llara kadar sürmüştür6 ${ }^{6}$. Yapı, Kültür ve Tabiat Varlıklarını Koruma Kurulu tarafından 1985 yılında tescillenerek koruma altına alınmıştır. Envanter numaras1 305 olan yapının parsel numaraları ise 935 ve 936'dir (Tablo 1). Bu yap1, 2001 yılında restore edilmeye başlanmış ve restorasyon çalışmaları 2003 yılında tamamlanmıştır. 2003 yılında yapı işlevlendirilmiş ve otel olarak kullanılmaya başlanmıştır. Böylece bir dönem Antakya'nın önemli sabunhanelerinden biri olarak faaliyet gösteren Şeyhoğlu Sabunhanesi, 2003 yılından günümüze kadar Savon Otel adıla faaliyet göstermektedir (Fotoğraf 2g). Bu yönüyle söz konusu tarihi yapı, endüstriyel miras turizmi kapsamında dikkatleri üzerine çeken önemli yapılardan birini oluşturmaktadır. Otele, sabun anlamına gelen Savon isminin verilmesi, Antakya'da sabun üretiminin ve sabunhanelerin kent kimliğini bakımından taşıdığı önemi de açıkça ortaya koymaktadır.

\subsubsection{Selahattin Ökten Sabunhanesi}

Kurtuluş Caddesinde, Savon Otelin hemen kuzeyinde yer alan Selahattin Ökten Sabunhanesinin XVI. yüzyllda bir kervansaray olarak inşa edildiği ve bu yapının XIX. yüzyılda sabunhane olarak faaliyet göstermeye başladığı bilinmektedir. Uzun yıllar sabunhane olarak işlev gören yapı bünyesinde 1995 yılında, Gülteks Dış Ticaret Limited Şirketi tarafından inşaat malzemeleri satışı ve iç dekorasyon faaliyetleri başlamıştır. Bu şirket, 2008 yılında tüketici ihtiyaçları doğrultusunda yenilikler ortaya koyarak, yüzylllara dayanan sabun kültürünü “Antioch's Verdaa" adı altında markalaştırmıştır?. Sabun kültürünün markalaşması ve sabunhanenin bir endüstriyel miras değerine sahip olması, Antakya'da sabun üretimine dayalı kent kimliğinin

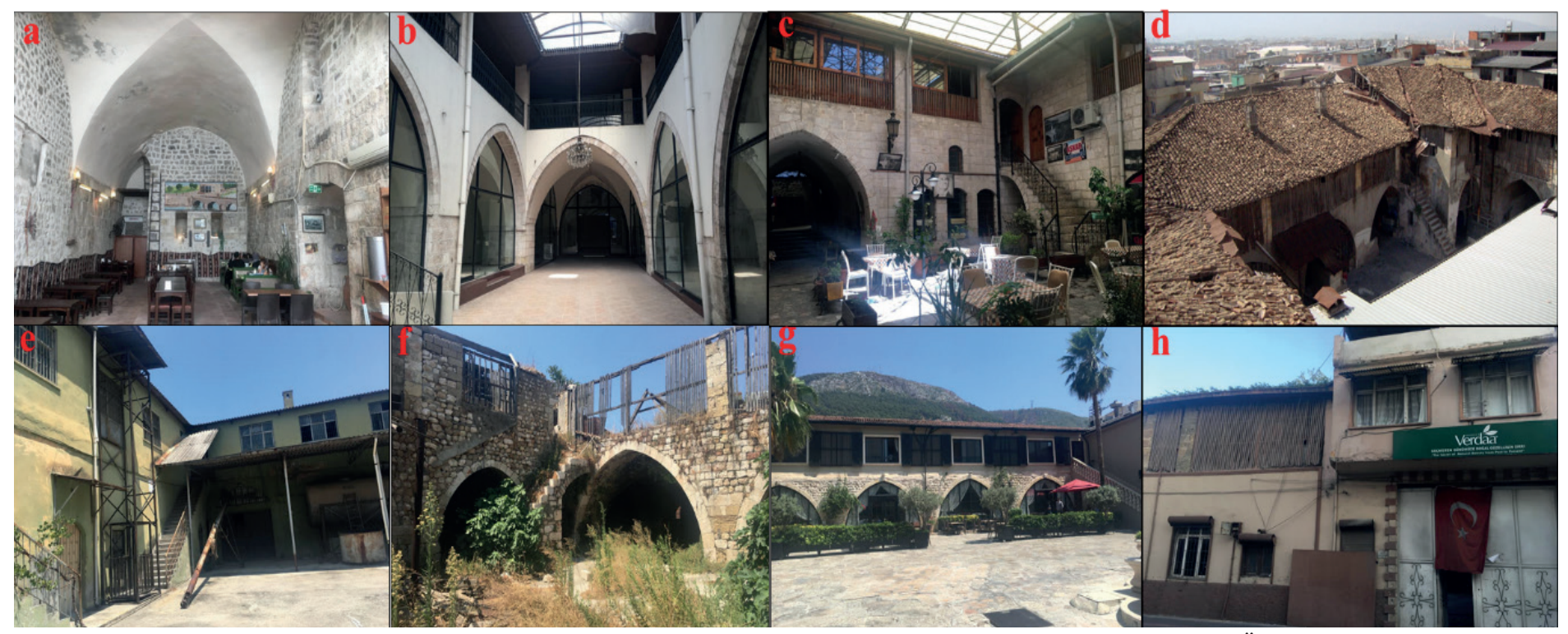

Fotoğraf 2: Araştırma Sahasında Yer Alan Sabunhanelerden Görünümler (2a: Bedesten Sokak Sabunhanesi, 2b: Ömer Şenek Sabunhanesi, 2c: Çelenkçioğlu Sabunhanesi, 2d: Kuseyri Sabunhanesi (Camuz, 2016), 2e: Hasan Ökten Sabunhanesi, 2f: Aselcioğlu Sabunhanesi,

2g: Şeyhoğlu Sabunhanesi, 2h: Selahattin Ökten Sabunhanesi)

Photo 2: Views from the soap factories in the research area (2a: Bedesten Street Soap Factory, 2b: Ömer Şenek Soap Factory, 2c: Çelenkçioğlu Soap Factory, 2d: Kuseyri Soap Factory (Camuz, 2016), 2e: Hasan Ökten Soap Factory, 2f: Aselcioğlu Soap Factory,

2g: Şeyhoğlu Soap Factory, $\mathbf{2 h}$ : Selahattin Ökten Soap Factory)

6 http://savonhotel.com.tr/savonhotel, Erişim Tarihi: 23.07.2019.

7 http://verdaa.com/kurumsal/detay/hakkimizda, (Erişim Tarihi: 24.07.2019) 
güçlenmesine neden olmaktadır. Kentsel sit alanı ve III. derece arkeolojik sit alanı içerisinde, 5. mıntıkada yer alan Selahattin Ökten Sabunhanesi, Adana Kültür ve Tabiat Varlıklarını Koruma Kurulu tarafindan 2005 yilında tescillenerek koruma altına alınmıştır. Envanter numarası 385 olan yapı, 2328 nolu parselde yer almaktadır (Tablo 1). Tarihi Selahattin Ökten Sabunhanesini Antakya'daki diğer eski sabunhanelerden ayıran en önemli özellik, bu yapının bünyesinde sabun üretimine günümüzde de devam ediliyor olmasıdır (Fotoğraf 2h). Sabunhanede, ulusal ve uluslararası standartlara uygun şekilde üretim yapılmakta, üretimin her aşamasında çeşitli analiz ve testler yapılmakta ve üretilen sabunlar başta Orta Doğu ülkeleri olmak üzere çeşitli ülkelere ihraç edilmektedir. ${ }^{8}$

\subsection{Antakya'da Endüstriyel Miras Turizmi (Sabunhaneler) Bakımından Bir Rota Önerisi}

Dünya genelinde, endüstri mirasının korunmasına yönelik olarak gerçekleştirilen çalışmalar içerisinde endüstriyel miras değeri taşıyan eserlerin bir rotasının oluşturulması bakımından en dikkat çekici çalışmalardan birini ERIH (The European Route of Industrial Heritage/ Avrupa Endüstri Miras1 Rotas1) oluşturmaktadır (Özdemir ve Öztürk, 2018, s. 374). Avrupa'da bulunan ve tarihi öneme sahip endüstriyel yapılara yönelik ortak rotalar öneren ERIH'in 2002-2007 yılları için geliştirmiş olduğu ilk projeden günümüze endüstri rotaları genişlemiş ve genişlemeye devam etmektedir (Kıraç, Coşkun ve Erdoğan, 2018, s. 83). 2019 yılında ERIH'e üye olan ülkelerin sayısı 26 olup, bu ülkelerdeki toplam endüstriyel alan sayıs1 1800'ün üzerindedir. Türkiye, Santral-İstanbul Enerji Müzesiyle ERIH'e üye olmuştur. Ülkemizde, ERIH rotasına dâhil olan toplam altı güzergâh noktası yer almaktadır. İstanbul'da Santral-İstanbul dışında, İstanbul Havacılık Müzesi, Rahmi Koç Endüstri Müzesi, İstanbul Demiryolu Müzesi, İzmit’te yer alan Seka Kâğıt Müzesi ve İzmir'de yer alan Çamlık Buharlı Lokomotif Müzesi bu endüstriyel alanları oluşturmaktadır?.

Avrupa'nın endüstriyel miras değerlerine yönelik olarak geliştirilen rotalardan farklı olarak, Türkiye'de yerel ve bölgesel ölçekte endüstriyel miras rotası öneren çalışmalar da vardır (Köksal ve Ahunbay, 2006; Yılmaz, 2014). Ancak bu çalışmaların sayısı oldukça azdır. Ülkemizde çoğunluğu Osmanlı döneminde kurulmuş ve günümüze kadar ayakta kalabilmiş olan tarihi öneme sahip endüstriyel yapılara hemen her şehirde rastlamak mümkündür. Bu yapıların çoğu, 1950’li yıllara kadar aktif iken, daha sonraki süreçte çeşitli sebeplerle faaliyetlerini durdurmak zorunda kalmışlardır. Şüphesiz bunun temel sebeplerinden biri Özdemir (2015)'in de belirttiği gibi, 1950'li yıllardan itibaren üretim sistemleri ve tüketici ihtiyaçlarında meydana gelen değişimlerdir (Özdemir, 2015). Gerçekten de belirtilen dönemde geleneksel yöntemlerle üretim yapan endüstriyel tesisler zamanla işlevlerini yitirerek birer endüstri mirası olarak kalmışlardır. Antakya'da yer alan sabunhaneler de bunun bir örneğini oluşturur.

Son yıllarda, Asi Nehri ile Habib-i Neccar Dağı arasında yer alan ve "Eski Antakya" olarak bilinen alanın kültür turizmi bakımından daha fazla dikkat çekmeye başlaması, bazı sokakların araç trafiğine kapatılmasını gündeme getirmiştir. Nitekim birkaç yıl önce trafiğe kapatılan Saray Caddesi’nden sonra günümüzde de Kurtuluş Caddesi'nin yayalaştırma projesi kapsamında araç trafiğine kapatılması gündeme gelmiştir. $\mathrm{Bu}$ durum, Eski Antakya'ya gelen turistlerin şehrin tarihi dokusunu yürüyerek gezmelerini beraberinde getirecektir. Böylece, günümüzde dar ve dolambaçlı Antakya sokaklarının gastronomi, kafeler vb. gibi amaçlarla kullanılması artık daha fazla teşvik edilmektedir. Bu sayede, bir takım kültür öğelerinin belirli sokaklarda yoğunluk kazanması amaçlanarak, turistlerin şehirdeki kültür öğelerini bir arada görebilecekleri yeni güzergâhlar (rotalar) önerilebilmektedir. Bu çalışmada da önemli birer endüstriyel miras değeri taşıyan sabunhanelere yönelik bir rota önerisi getirilmiştir.

Sabunhanelere yönelik rota; Hatay Valiliği'nden başlayarak, Hürriyet (Saray) Caddesi, Uzun Çarşı Caddesi ve Tayfur Sökmen Caddesi üzerinden Suphi Bedir Uluç Sokak'a ve buradan da Kurtuluş Caddesi ile birleşerek Selahattin Ökten Sabunhanesine (Verdaa) kadar uzanmaktadır (Şekil 3). Bu rota yaklaşık 1,5 kilometre uzunluğa sahiptir. Hatay Valiliği'nden sabunhane rotasının ilk durağını oluşturan Bedesten sokaktaki sabunhaneye kadarki güzergâhı oluşturan caddenin adı Hürriyet (Saray) Caddesi'dir. Rota üzerinde, ilk önemli tarihi yapıyı Valilik Binası oluşturmaktadır. Anadolu şehirlerinde, tanzimatın ilan edilmesinden sonraki süreçte hükümet konağ $1 \mathrm{vb}$. gibi yapıların hizmete girmesiyle idari merkez artık surların dışına çıkmaya başlamıştır. Mısır Valisi Kavalalı Mehmet Ali Paşa'nın oğlu İbrahim Paşa, 1832-1840 yılları arasında Kurtuluş Caddesi girişindeki (güneyden) bugünkü kışlayı inşa ettirdikten sonra valilik binası olarak kullanılan yapıyı da saray olarak inşa ettirmiştir (Temiz, 2002, s. 116).

8 Verdaa sabun fabrikası genel müdürü Gülay Gül ile yapılan mülakat (Mülakat Tarihi: 05.07.2019)

9 https://www.erih.net/, (Erişim Tarihi: 09.09.2019). 
Valilik binasının önünde (kuzeybatısında) bir asırdan daha fazla tarihi geçmişe sahip olan ve bugün okul olarak (Ata Koleji) kullanılan tarihi bina yer almaktadır. Bu binanın yapımına 1900 yılında başlanmış ve bina 1909 yılında kullanıma hazır hale getirilmiştir. Söz konusu tarihi yapı, Kuzey Suriye Mebusu Rıfat Bereket tarafından yaptırılmıştır. Önceleri bir konak olarak kurulan ve 1920 yılında turizm oteli haline getirilen bina, Hatay'ın anavatana katıldığı 1939 yılında Antakya Belediyesine devredilmiştir. Bina 1961 yılında kız öğretmen okuluna tahsis edilmiş ve 1962 yılında Özel Ata Koleji adıyla eğitim-öğretime hizmet vermeye başlamıştır. ${ }^{10}$

Valilik binasının yaklaşık 30 metre kuzeydoğusunda yer alan Protestan Kilisesi, 1800'lü yıllarda Fransız konsolosluğu olarak inşa edilmiş, daha sonraki yıllarda Suriye Bankası olarak kullanılmıştır. 1940-1970 yılları arasında Şeyhoğlu ailesi tarafindan ev, 1970-1980'li yıllarda ise İl Emniyet Müdürlüğü tarafindan Toplum Polis binas1 olarak kullanılan yap1, 1999 yılında Güney Koreliler tarafından satın alınarak Protestan Kilisesi'ne dönüştürülmüştür (Mısırlığlu, 2013, s. 70). Saray Caddesinin araç trafiğine kapatılmış olan bölümünde, Saray Caddesi ile Gazipaşa Caddesi arasında yer alan Ortodoks Kilisesinin İbrahim Paşa'nın izni ile 1833 yılında inşa edilmiş olduğu bilinmektedir. Ancak yapı, 1872 yılında meydana gelen deprem nedeniyle yıkılmış ve yerine bugünkü kilise binası yeniden inşa edilmiştir. Bina, 2000 yılında altı aylık bir restorasyon sürecine girmiştir (Mısırlığlu, 2013, s. 68).

Hürriyet Caddesinin kuzey kesiminde gerçekleştirilen kanalizasyon çalışmaları sırasında tarihi su kemeri bulunmuş ve bu kemer koruma altına alınmıştır. Hürriyet Caddesi ile Kırk Asırlık Türk Yurdu Caddesinin kesiştiği noktada Ulu Cami yer almaktadır. Caminin Memluk sultanlarından Baybars tarafindan 1271-1272 tarihinde inşa edilmiş olduğu ileri sürülmektedir. Caminin minaresinin Osmanlı Döneminde, Sokullu Mehmet Paşa tarafından yapıldığı, birkaç defa onarım gördüğü ve Osmanlı mimarisine uygun olarak restore edilmiş olduğu bilinmektedir (Şancı, 2006, s. 43). Ulu Caminin hemen arkasında (kuzeyinde), Bedesten Sokak ile Bekir Sitkı Kunt Caddesi arasında tarihi bir sabunhane yer almaktadır. Bu sabunhane, Eski Antakya'daki sabunhaneler rotasının ilk durağını oluşturmaktadır (Şekil 3). Bu sabunhaneden doğuya doğru gidildikçe, çoğunluğu işlevsel dönüşüme uğramış geleneksel Antakya evleri ile dar ve dolambaçlı sokakların yer aldığı dikkati çekmektedir. Sabunhanenin hemen kuzeyinde Abacılar çarşısı, Kemalpaşa
Caddesi ve Uzun Çarşı Caddesinin kesiştiği noktada Ömer Şenek Sabunhanesi yer almaktadır (Şekil 3). Restorasyon halinde olan Ömer Şenek Sabunhanesi, rotanın ikinci durağını oluşturmaktadır.

Sabunhaneler rotasi, Ömer Şenek Sabunhanesinden sonra Uzun Çarşı Caddesi üzerinden devam etmektedir (Şekil 3). Osmanl1-Türk kültürünün yapısal özelliklerini yansıtan Uzun Çarşı, Antakya'nın tarihi ticaret merkezini oluşturmaktadır. Bu sahada, birbirinden farklı faaliyet kollarında hizmet veren dükkânların yanı sıra, tarihi öneme sahip camiler, han ve hamamlar yer almaktadır (Üçeçam Karagel ve Karagel, 2014, s. 75). Uzun çarşıya Kemalpaşa Caddesi üzerinden girildiğinde, çarşının giriş kısımlarında ayakkabı ve çanta satan dükkânların yer aldığ 1 görülmektedir. Çarşı girişinden iç kısımlara doğru yaklaşık 100 metre kadar mesafe kat edildiğinde tarihi Kurşunlu Han ile karşılaşılmaktadır. 1660 yılında Köprülü Mehmet Paşa tarafindan Sürre alayının ağırlanması için inşa ettirildiği bilinen Kurşunlu Han, Antakya'da yer alan hanların en eskisi olma özelliğine sahiptir ${ }^{11}$.

Kurşunlu Han geçildikten sonra, künefe ve baharat dükkânları ile karşılaşılmaktadır. Uzun Çarşı Caddesinden, Tayfur Sökmen Caddesinin girişine kadarki güzergâh içerisinde baharatçıların, defne sabunu satan dükkânların, künefecilerin ve kuruyemişçilerin yoğun olduğu dikkati çekmektedir. Tayfur Sökmen Caddesine girildiğinde, sabunhane rotasının üçüncü durağını oluşturan Çelenkçioğlu Sabunhanesi (Defne Han) ile karşılaşılmaktadır (Şekil 3). Geçmiş dönemlerde sabunhane olarak kullanılan bu yapı bünyesinde günümüzde giyim ve züccaciye dükkânları faaliyet göstermektedir. Sabunhanenin hemen yanında (kuzeyinde) tarihi Saka Hamamı yer almaktadır. Sokullu Mehmet Paşa tarafindan XVI. yüzyılda inşa edilmiş olduğu tahmin edilen Saka Hamam1, Mahremiye Camiinin kuzeybatısında, yol seviyesinden daha düşük bir alanda yer almaktadır (Şanc1, 2006, s. 348-350). Saka Hamamının yaklaşık 100 metre kuzeyinde, İnne İplik Caddesi üzerinde ve Atahan İşhanı'nın hemen karşısında, rotanın dördüncü durağını oluşturan Kuseyri Sabunhanesi yer almaktadır. Kuseyri Sabunhanesi ile daha kuzeyde yer alan Suphi Bedir Uluç Sokak'a kadar uzanan alanda, Tayfur Sökmen Caddesi üzerinde seyyar satıcıların faaliyet gösterdiği dikkati çekmektedir.

Suphi Bedir Uluç Sokağı üzerinde iki sabunhane yer almaktadır (Şekil 3). Bunlardan biri Hasan Ökten Sabunhanesi diğeri ise Aselcioğlu Sabunhanesidir. Aselcioğlu Sabunhanesinin hemen doğusunda, Kurtuluş Caddesi üzerinde Şeyhoğlu Sabunhanesi yer

10 (www.antakyaatakoleji.k12.tr) (Erişim tarihi: 05.09.2019).

11 http://www.hatay.bel.tr, Erişim Tarihi: 04.09.2019. 


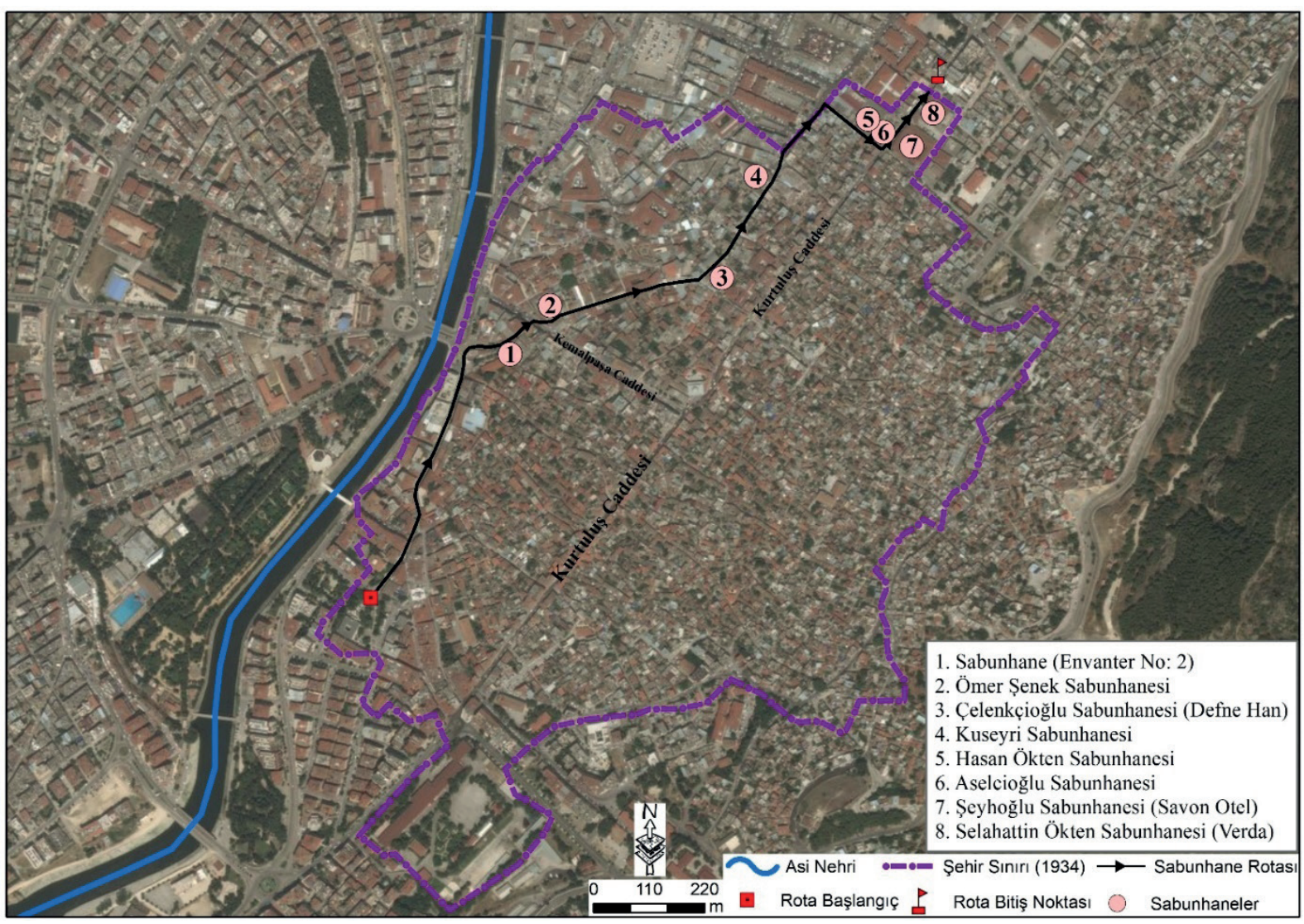

Şekil 3: Antakya'daki Endüstriyel Miras Turizmine Yönelik Geliştirilen Rota Önerisi (Antakya'nın 1934 yılı şehir sınırı Weulersse (1934)'ün çizmiş olduğu bir harita üzerinden yeniden çizilerek oluşturulmuştur.)

Figure 3: A route suggestion for industrial heritage tourism in Antakya (The city border of Antakya in 1934 was created by redrawing on a map drawn by Weulersse (1934)).

alır. Günümüzde Savon adıyla bilinen bir otel olarak hizmet veren bu yapının da yaklaşık 50 metre kuzeyinde "Verdaa" adı altında geleneksel sabun üretimine devam eden tarihi Selahattin Ökten Sabunhanesi yer almaktadır. Bu sabunhane, sabunhaneler rotasının son durağını oluşturur (Şekil 3). Antakya şehrinin 1930'lu yıllardaki sınırına dikkat çekildiğinde, Kuseyri Sabunhanesinden Selahattin Ökten Sabunhanesine kadar uzanan güzergâhtaki toplam beş sabunhanenin, o dönemlerde şehrin ana ulaşım aksını oluşturan Kurtuluş Caddesinin kuzey sınırında ve bir arada yer aldıkları görülmektedir. $\mathrm{Bu}$ nedenle, bu saha şehrin adeta sabunhaneler bölgesini oluşturmaktadır (Şekil 3). Roma döneminde Colonnaded Street (Kolonadlı Cadde) adıyla bilinen Kurtuluş Caddesi (Kışla-Dörtayak Yolu) ilk defa 1929-1935 yılları arasında Fransızlar tarafından trafiğe açılmıştır (Temiz, 2002:119). Böylece sabunhanelerin ilk defa 1930'lu yıllarda şehrin yerleşim sahasına dâhil oldukları anlaşıılmaktadır.

\section{SONUÇ}

Bu çalışmada, Antakya'da sabun üretiminin, kent kimliğini oluşturan öğeler arasında önemli bir yere sahip olduğu ortaya konulmuştur. Kuruluşu antik döneme kadar uzanan kentte, Daphne (Defne) mitolojisinin hala yaşatıllyor olması, Defne isminin yöresel bir ad olarak yeni doğan çocuklara verilmesi, bazı büyükşsehirlerde düzenlenen Hatay Tanıtım Günlerinde sabun stantlarına yer verilmesi, resmi ve özel kurumların logolarında defne ve zeytin yapraklarının yer alması, defne bitkisinin ve defne sabununun kent kimliği bakımından ne kadar önemli olduğunu göstermektedir. Diğer yandan, XIX. yüzyılda sabunculuk mesleğinin kentteki önemli meslekler arasında sayılması, sabun üretim kültürünün ve kullanımının geçmişte olduğu gibi günümüzde de devam ediyor olması ve üretimin belirli kurumlar aracılığıyla markalaştırılması gibi faktörler de sabun üretiminin kent kimliği bakımından önemini ortaya koymaktadır.

Arazi çalışmalarından elde edilen gözlemelere ve daha önceden yapılmış olan çalışmaların bulgularına dayanarak, Antakya'da belirli dönemlerde sabunhane olarak kullanılan yapıların XIX. yüzyılda faaliyet göstermeye başladıkları ve XX. yüzyılın ikinci yarısından sonra da işlevlerini yitirdikleri ortaya konulmuştur. İşlevlerini yitiren sabunhaneler, 1982-2005 y1lları arasında tescillenerek koruma altına alınmışlardır. Weulersse'nin 
1934 yılında çizmiş olduğu Antakya şehir haritası üzerinde sabunhaneler konumlandırıldığında, bu sabunhanelerin tarihi ticaret merkezinde ve şehrin kuzey kenarında toplanmış olduğu dikkati çekmiştir. Sabunhaneler, Eski Antakya'da yer alan otellerde konaklayacak yerli ve yabancı turistlerin doğrudan temas kurabilecekleri bir sahada yer almaktadır. $\mathrm{Bu}$ durum Antakya'nın tarihi dokusunu gezen turistlerin belleklerinde birçok kültür öğesinin yanı sıra sabun üretiminin ve sabunhanelerin de yer edinmesi bakımından önem arz etmektedir.

Günümüzde, araştırma sahasında tespit edilen sabunhanelerin dört tanesinin işlevlendirilmiş, diğer dört tanesinin ise henüz işlevlendirilmemiş olduğu ortaya konulmuştur. İşlevlendirilmiş sabunhanelerden Şeyhoğlu Sabunhanesi otel (Savon Otel) olarak kullanılmakta, Selahattin Ökten Sabunhanesi "Verdaa" adı altında geleneksel sabun üretimine devam etmekte, Çelenkçioğlu Sabunhanesinde giyim ve züccaciye dükkânları faaliyet göstermekte, Bedesten Sokakta yer alan sabunhane ise restoran ve künefeci dükkânları olarak hizmet vermektedir. Ömer Şenek Sabunhanesi ile Kuseyri Sabunhanesi restorasyon aşamasında olup, Aselcioğlu Sabunhanesi ile Hasan Ökten Sabunhanesi ise restore edilmesi gereken yapılardır.

Son yıllarda Antakya, tarih ve kültür turizmi yönüyle dikkatleri üzerine çekmiştir. Bu durum, kent kimliğini oluşturan farklı kültürel öğelere yönelik farkındalığı arttırmıştır. Bu çalışmada, Antakya'da kimlik-kültür-turizm etkileşimine sabunhaneler örneğiyle dikkat çekmek için bir endüstri mirası rotası geliştirilmiştir. Diğer yandan rota önerisinin geliştirildiği sabunhanelerden farklı olarak, birkaç yıl önce trafiğe kapatılan Saray Caddesinden sonra, günümüzde Kurtuluş Caddesinin de trafiğe kapatılmasının gündeme gelmesi şüphesiz yeni kültür rotalarının oluşturulabileceği konusunda sinyaller vermektedir.

\section{Öneriler}

Antakya'nın tarihi dokusunu oluşturan Eski Antakya'nın sınırları içerisinde geleneksel konutlardan, han ve hamamlara, çeşmelerden ibadethanelere kadar birer kültür mirası niteliği taşıyan ve koruma altına alınmış olan çok sayıda tarihi yapı yer almaktadır. Bu yapıların yanı sıra, kentte yaklaşık bir asırdan fazla bir süre sabunhane olarak faaliyet göstermiş olan ve endüstri mirası bakımından büyük önem arz eden yapılar da vardır. Sabun üretim kültürü, kent kimliğini oluşturan öğelerden biri olarak dikkat çekse de sabunhanelere yönelik bir farkındalığın henüz oluşturulmamış olduğu ve bazı sabunhanelerin metruk durumda kaldığ1 görülmüştür. $\mathrm{Bu}$ nedenle, söz konusu sabunhanelerin ve kentte metruk durumda bulunan diğer tarihi yapıların restore edilip, koruma kullanma kapsamında işlevlendirilmesi önemli bir gerekliliktir.

Restore edilip yeniden işlevlendirilecek olan sabunhanelerin bünyesinde, geleneksel sabun üretimi canlandırılabilir, bu sabunhanelerde müze, restoran, kafe gibi amaçlarla hizmet verilebilir. Şüphesiz bu durum, sürdürülebilirlik bakımından kent kimliğini tarih ve kültür turizmiyle buluşturacak önemli bir adım olacaktır. Tarihi sabunhanelere yönelik kurulacak olan en yakın temas, bu yapıların "Savon Otel" örneğinde olduğu gibi birer otel olarak hizmete açılması ve turistlerin bu otellerde konaklamalarının sağlanmasıdır. Bu çalışmada bir öneri olarak geliştirilen sabunhaneler rotasının yararlı sonuçlar vermesi durumunda, bu rotanın ülkemizdeki diğer endüstri mirası rotalarılla ve ERIH ile entegrasyonu sağlanabilir.

Hakem Değerlendirmesi: Dış bağımsız.

Çıkar Çatışması: Yazarlar çıkar çatıșması bildirmemiștir.

Finansal Destek: Yazarlar bu çalışma için finansal destek almadığını beyan etmiştir

Peer-review: Externally peer-reviewed.

Conflict of Interest: The authors have no conflict of interest to declare.

Grant Support: The authors declared that this study has received no financial support.

\section{KAYNAKLAR}

Ahmet Rifat Efendi, (1881). Lugat-l tarihiyye ve coğrafiyye. İstanbul, cilt: I, 674-678.

Ali Cevad Bey. (1895). Memalik-i Osmaniye'nin tarih ve coğrafya lugatı, İstanbul, 34-36.

Aly, S.S.A. (2011). Modernization and regionalism: approaches for sustainable revival of local urban identity, Procedia Engineering. 21,503-512

Ayçiçek, M. (2017). Antakya şehrinin sosyal ve ekonomik durumu (1865-1866). A. Gündüz ve H. Çoruh (Ed.) Hatay Araştırmaları III. 89-106. Ankara: Pozitif Matbaa Yayıncılık.

Aydın, D. ve Aksoy, E. (2012). Endüstri yapılarında yeniden kullanılabilirlik: Nazilli Sümerbank fabrikasının sosyal tesis binasının işlevsel dönüşümü için analizler. 24. Uluslararası Yapı ve Yaşam Kongresi (5-6-7 Nisan 2012), ss.250-264. Bursa.

Baalawi, M. (2016). "Kentsel kimlik alglsl ve kent kültürü örnek: bursa kentinin kimliği üzerine gençlerin düşünceleri”, (Yüksek Lisans Tezi). Uludağ Üniversitesi, Bursa.

Barbaros Akay, E. ve Örmercioğlu, H.T. (2018). Endüstri yapılarının kültürel miras olarak değerlendirilmesi: antalya tekirova maden işleme tesisi örneği. Uluslararası Sosyal Araştırmalar Dergisi, $11(60), 488-498$

Camuz, D. (2016). Conservation of kuseyri soap factory as an industrial herltage in Antakya. (Yüksek Lisans Tezi). İzmir Yüksek Teknoloji Enstitüsü, İZMIR. 
Camuz, D. İpekoğlu, B., Böke, H., (2015). Tarihi osmanlı sabunhaneleri: Anktaya kuseyri sabunhanesi'nin mimari özellikleri ve koruma sorunları, Kargir Yapılarda Koruma ve Onarım Semineri VII Bildiri Kitabı, 10-26.

Çelenk, Y. (1996). Antakya Sokollu Mehmed Paşa Hanı restorasyonu. (Yüksek Lisans Tezi). İstanbul Teknik Üniversitesi, İstanbul.

Dinç, Y. (2015). Antakya şehir coğrafyası, (Yüksek Lisans Tezi), Mustafa Kemal Üniversitesi, Hatay.

Göney, S. (2017). "Şehir coğrafyası I" M. Bayartan (Ed.), 4.bask1, İstanbul:Beta Basım.

Hınz, W. (1990). İslamda ölçü sistemleri (A.Sevim, Çev.). Edebiyat Fakültesi Basımevi, İstanbul.

Karadağ, A. ve İncedere, L. (2017). Türkiye'de endüstri mirasının korunması, Türkiye Coğrafyası Araştırmaları Prof. Dr. Mesut Elibüyük'e Armağan kitabı içinde, F. Arslan (Ed.), ss.13-42, Pegem Akademi.

Kaya, B. veAladağ, C. (2009). Maki ve garig topluluklarının Türkiye'deki yayılış alanları ve ekolojik özelliklerinin incelenmesi. Selçuk Üniversitesi Sosyal Bilimler Enstitü Dergisi, (22), 67-80, Konya.

Kıraç, A.B. Coşkun, B.S. ve Erdoğan, D. (2018). Küçükçekmece Osmanlı kibritleri fabrikasının endüstriyel miras kapsamında değerlendirilmesi. Megaron Dergisi, 13(1), 67-84.

Koruma Uygulama ve Denetim Bürosu (KUDEB), Tescil fişleri ve 1/1000 ölçekli koruma amaçlı imar planı, Hatay.

Koyuncu, A. (2013). Kimliğin inşasında kent: Konya örneği, Akademik Incelemeler Dergisi, 8(2), 155-179.

Köksal, G.T. ve Ahunbay, Z. (2006). İstanbul'daki Endüstri Mirası İçin Koruma ve Yeniden Kullanım Önerileri, ITÜ Dergisi/a mimarlı, planlama, tasarım, 5(2), 125-136, İstanbul.

Kaypak, Ş. (2010). Antakya'nın kent kimliği açısından irdelenmesi, Mustafa Kemal Üniversitesi Sosyal Bilimler Enstitüsü Dergisi, 7(14),373-392, Hatay.

Mersinligil, Ö ve Erişen, O. (1996). Antakya imar planı ön araştırması, Antakya.

Misırlığlu, S. (2013). Hatay: şehr-i kutsalım. Antakya Belediyesi Kültür Yayınları, Antakya.

Özdemir, M. (2015). Endüstri mirasının yeniden işlevlendirilmesi; Beykoz deri ve kundura fabrikası örneği. (Yüksek Lisans Tezi). İstanbul Teknik Üniversitesi, İstanbul.

Özdemir, M. ve Öztürk, M. (2018). İstanbul kenti endüstriyel miras rotası oluşturulması. IV.IMCOFE Konferansı Bildiriler Kitabı, ss.370-377, Roma.

Polat, S. Polat Aktaş, S., Halis, M., (2013). Kent kimliği kapsamında festivallerin değerlendirilmesi: Uluslararası Altın Safran Film Festivali örneği, Turizm \& Araştırma Dergisi, 2(1)48-63.

Sargın, S. Dinç, Y. (2017). Kültür mirasının korunmasına yönelik mekânsal bir değerlendirme: eski (geleneksel) Antakya evlerinin fonksiyonel değişimi, Turkish Studies, (12/13), 477-506.
Saner, M. (2012). Endüstri miras1: kavramlar, kurumlar ve Türkiye'deki yaklaşımlar, Planlama Dergisi (1-2), 53-66.

Şanc1, F. (2006). Hatay ilinde türk mimarisi. (Doktora Tezi). Ankara Üniversitesi, Ankara.

Temiz, F.M. (2002). XIX. yüzyıl ve sonrasında Antakya'nın kentsel mekan oluşumunda meydana gelen değişiklikler ve Kurtuluş caddesi, Yüzüncü Yıl Üniversitesi Sosyal Bilimler Enstitüsü Dergisi, Van.

Temiz, F. M. (2008). Antakya'da sabun üretimi ve sabunhaneler. Hatay Kültür ve Keşif Dergisi, 14(2), 14-16.

Türk, M. (2012). Ebu Ubeyde Bin Cerrah'in (R.A.) hediyesi Antakya, Antakya Belediyesi Kültür Yayınları, Hatay.

Türk Dil Kurumu Sözlükleri, https://sozluk.gov.tr/ (Erişim tarihi: 06.06.2019)

Üçeçam Karagel, D., Karagel, H., (2014). Analysis of a Historical commercial centre in terms of marketing geography: Uzun Çarş1/ the Long Bazaar (Antakya/Turkey), European Journal of Research on Education, 2, 166-184.

Weulersse, J. (1934). Antioche esadi de geographié urbanie. Bulletin d'Etudes Orientales, 4(2), 27-72.

Y1lmaz, H. (2014). Eskişehir'in biricik destinasyon önerisi: endüstriyel miras. Dokuz Eylül Üniversitesi İktisadi ve İdari Bilimler Fakültesi Dergisi. 29(2), 205-225.

\section{Internet Kaynakları}

http://ticcih.org/about/charter/, (Erişim Tarihi: 03.09.2019)

www.antakyaatakoleji.k12.tr (Erişim Tarihi: 05.09.2019)

http://www.hatay.bel.tr, (Erişim Tarihi: 04.09.2019).

http://verdaa.com/kurumsal/detay/hakkimizda, (Erişim Tarihi: 24.07.2019)

http://savonhotel.com.tr/savonhotel, (Erişim Tarihi: 23.07.2019). https://www.erih.net/, (Erişim Tarihi: 09.09.2019).

https://twitter.com/expohatay2021,(ErişimTarihi:23.07.2019). http:// www.hatsu.gov.tr/icerik.php?bolum $=3 \& n o=9, \quad$ (Erişim $\quad$ Tarihi: 23.07.2019).

https://www.defne.bel.tr/haberler/duyurular/, (Erişim Tarihi: 23.07.2019).

http://www.defnehastanesi.com/cocukcerrahisi.html, (Erişim Tarihi: 23.07.2019).

https://twitter.com/hataybsb, (Erişim Tarihi: 23.07.2019).

https://www.linkedin.com/company/antakyatso, (Erişim Tarihi: 23.07.2019).

https://twitter.com/altinozubld, (Erişim Tarihi: 23.07.2019). http://www.futbollogo.com/takim.php?id=141, (Erişim Tarihi: 23.07.2019). 